\title{
ARTICLES
}

Submitted 07.27.2013. Approved 10.25.2013

Evaluated by double blind review process. Scientific Editor: Sergio Bulgacov

http://dx.doi.org/10.1590/So034-759020140510

\section{COGNITIVE LEGITIMACY, RESOURCE ACCESS, AND ORGANIZATIONAL OUTCOMES}

\author{
Legitimidade cognitiva, acesso aos recursos e resultados organizacionais \\ Legitimidad cognitiva, acceso a recursos, y resultados organizativos
}

\begin{abstract}
Previous research has demonstrated the importance of developing legitimacy initiatives in order to create new business opportunities, satisfy shareholders, and obtain access to resources. Within this framework, cognitive legitimacy plays a key role. Through a case study of six Spanish public universities, the authors measure the relationship between cognitive legitimacy, access to resources, and organizational results. The results support the assertion that organizations with more cognitive legitimacy have greater access to resources and improved their results. This study contributes with muchneeded empirical research on cognitive legitimacy and demonstrates its usefulness as an explanative factor of organizational success.
\end{abstract}

KEYWORDS | Legitimacy, institutional theory, cognitive legitimacy, organizational results, resources acquisition.

\section{RESUMO}

Pesquisas prévias indicaram a importância de desenvolver iniciativas de legitimidade, a fim de criar novas oportunidades de negócio, satisfazer os acionistas e obter acesso aos recursos. Dentro desta estrutura, a legitimidade cognitiva desempenha um papel fundamental. Através deste estudo de caso de seis universidades públicas espanholas, os autores medem a relação entre a legitimidade cognitiva, acesso aos recursos e resultados organizacionais. Os resultados apoiam a afirmação de que as organizações com maior legitimidade cognitiva possuem maior acesso aos recursos e, portanto, melhoraram os seus resultados. Este estudo contribui com a pesquisa empírica muito necessária sobre legitimidade cognitiva e demonstra a sua utilidade como um fator explicativo de sucesso organizacional.

\section{ANA CRUZ-SUAREZ}

ana.cruz@urjc.es

Professor at Department of Business Economics, Universidad Rey Juan

Carlos - Madrid, Spain

\section{ALBERTO PRADO-ROMÁN}

alberto.prado@urjc.es

Professor at Department of Business

Economics, Universidad ReyJuan

Carlos - Madrid, Spain

\section{MIGUEL PRADO-ROMÁN}

miguel.prado@urjc.es

Professor at Department of Business

Economics, Universidad Rey Juan

Carlos - Madrid, Spain
PALAVRAS-CHAVE / Legitimidade, teoria institucional, legitimidade cognitiva, resultados organizacionais, aquisição de recursos.

\section{RESUMEN}

Investigaciones anteriores han demostrado la importancia de desarrollar iniciativas de legitimidad para crear nuevas oportunidades de negocio, satisfacer a los accionistas, y obtener acceso a los recursos. En este marco, la legitimidad cognitiva juega un papel clave. Por medio de un estudio de caso de seis universidades públicas españolas, los autores miden la relación entre la legitimidad cognitiva, el acceso a los recursos, y los resultados organizativos. Los resultados apoyan la afirmación de que las organizaciones con mayor legitimidad cognitiva tienen un mayor acceso a los recursos y mejores resultados organizativos. Este estudio contribuye a la necesidad de mayor investigación empírica sobre la legitimidad cognitiva, demostrando su utilidad como un factor que explica el éxito de las organizaciones.

PALABRAS CLAVE / Legitimidad, teoría institucional, legitimidad cognitiva, resultados organizativos, acceso a recursos. 


\section{INTRODUCTION}

Over time, Institutional Theory has evolved into one of the main theories of Organization and Management (Haveman \& David, 2008). Organizations have a tendency to become institutionalized in order to survive. To do so, they must cultivate their legitimacy (DiMaggio and Powell, 1983; Zucker 1987). Its importance lies in the fact that the desirability and acceptance of an organization's activities allows it to maintain the support of key constituencies. Besides, legitimacy facilitates access to other resources that are necessary for survival and growth (Zimmerman \& Zeitz, 2002). Recently, research has shown that there are a growing number of firms developing legitimacy initiatives. These include corporate social responsibility programs, because they believe that they are a source of competitive advantage that will help them create new business opportunities, protect their company from regulation, or satisfy their shareholders (Bronn \& Vidaver-Cohen, 2009). Pollack, Rutherford, \& Nagy, (2012, p. 932) clearly state that "resources will be granted after legitimacy is achieved."

Previous authors have studied different aspects of the legitimacy process, from the strategic actions that favor organizational legitimacy (Aldrich \& Fiol, 1994; Suchman, 1995; Zimmerman \& Zeitz, 2002; Li, Yang, \& Yue, 2007; Rutherford \& Buller, 2007; Rao, Chandy, \& Prabhu, 2008; Lamberti \& Lettieri, 2011; Riquel \& Vargas, 2013); through the theoretical classification of legitimacy types (Scott, 1995; Suchman, 1995); to the relationship between legitimacy-development strategies and organizational goals (Bansal \& Clelland, 2004; Alcantara, Mitsuhashi, \& Hoshino, 2006; Barreto \& Baden-Fuller, 2006; Tornikoski \& Newbert, 2007; Low \& Johnston, 2008; Mitra, 2009; DíezMartín, Prado-Román, \& Blanco-González, 2013a).

Despite these studies, some blind spots still exist in our knowledge of legitimacy that this study attempts to clarify. Since Zucker (1989) or Suchman's (1995) requests for more studies on the different types of legitimacy, not much has been written to explain the relationships between the different types of legitimacy and organizational survival. Empirical studies have analyzed the effects of technical and management legitimacy on hospital survival (Ruef \& Scott, 1998); environmental legitimacy on stock market risk (Bansal \& Clelland, 2004); or even sociopolitical (Deeds, Mang, \& Frandsen, 2004), cognitive (Choi \& Shepherd, 2005; Pollack, Rutherford \& Nagy, 2012), and top management team legitimacy (Cohen \& Dean, 2005; Higgins \& Gulati, 2003, 2006) on IPO resource attraction.

The literature shows that there is not yet a canonical categorization of legitimacy types. However, among the different types of legitimacy, cognitive legitimacy has been identified as the most durable (Suchman, 1995) and, probably, the most efficient. Cognitive legitimacy can be broadly defined as how well organizations execute their activities from their stakeholder's point of view (Suchman, 1995). When organizations do not perform to a high enough level, they tend to disappear (Sheppard \& Chowdhury, 2005; Longenecker, Neubert, \& Fink, 2007). Legitimacy research has underlined, for some time already, the need to analyze the cognitive aspects of legitimacy empirically (Zucker, 1989). Recent research has shown that cognitive legitimacy plays a key role when entrepreneurs call for funding (Pollack, Rutherford, \& Nagy, 2012).

In this context, this paper aims to analyze the relationship between cognitive legitimacy and organizational survival empirically by studying the links between cognitive legitimacy and organizational resources and results. The current paper analyzes this phenomenon in public universities near Madrid (Spain).

\section{LITERATURE REVIEW}

From the mid-1990s, a critical mass of scholars has been asking how organizations acquire, manage, and use legitimacy. Initial efforts advanced towards a definition of the concept of legitimacy. In Institutions and Organizations, Scott (1995, p. 45) wrote that "legitimacy is not a commodity to be possessed or exchanged but a condition reflecting cultural alignment, normative support and consonance with relevant rules or laws." That same year, Suchman (1995, p. 574) published a definitive article where he put forward one of the most widely accepted definitions of legitimacy as "the generalized perception or assumption that an entity's actions are desirable, proper, or appropriate within some socially constructed system of norms, values, beliefs, and definitions." These two articles opened the gates to more published research on legitimacy. However, Aldrich and Fiol (1994) had previously shown the importance of legitimacy for entrepreneurs and somewhat later, Kostova and Zaheer (1999) analyzed legitimacy in the context of multinationals.

Literature shows legitimation as a process by which an entity's legitimacy changes over time (Maurer, 1971; Ashforth \& Gibbs, 1990). In general terms, legitimation could be considered as a parallel process to institutionalization (Lawrence, Winn, \& Jennings, 2001), although further research is needed. An example of this type of research is the work of Greenwood, Suddaby and Hinings (2002). Zimmerman and Zeitz (2002) defined legitimation as a set of actions that facilitate acquiring and maintaining legitimacy (Figure 1). Through this process, an organization has better access to strategic resources that allow it to grow and survive (Baum \& Oliver, 1991). 
Figure 1. Legitimation process

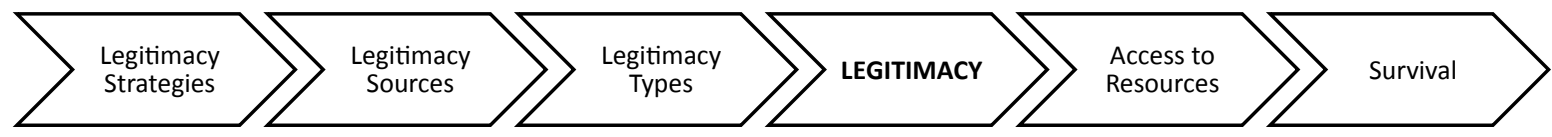

Source: Adapted from Zimmerman and Zeitz (2002:415)

Recent literature has analyzed different aspects of this process, though numerous elements and relationships still remain to be empirically tested. Some authors consider that legitimacy is a key element for organizational survival (Meyer \& Rowan, 1977; Zucker, 1987; Zimmerman \& Zeitz, 2002). Brown (1998, p. 35) states that "legitimate status is a sine qua non for easy access to resources, unrestricted access to markets, and long term survival". This assertion is supported by numerous investigations (Singh, Tucker, \& House, 1986; Baum \& Oliver, 1991, 1992; Hannan \& Carroll, 1992; Ruef \& Scott, 1998).

Interest in the study of legitimacy has extended into strategic management literature, given the possibility of manipulating legitimacy in order to achieve organizational goals (Suchman, 1995). Several strategic actions have been identified to improve legitimacy (Suchman, 1995; Deephouse, 1996; Zimmerman \& Zeitz, 2002; Lamberti \& Lettieri, 2011; Beelitz \& Merkl-Davies, 2012; Riquel \& Vargas, 2013). The effect of different legitimacy strategies on organizational survival has also been studied (Bansal \& Clelland, 2004; Alcantara, Mitsuhashi, \& Hoshino, 2006; Barreto \& Baden-Fuller, 2006; Tornikoski \& Newbert, 2007; Low \& Johnston, 2008).

Within the analysis of legitimation, certain authors speculate that some types of legitimacy are more difficult to achieve and of longer duration (Suchman, 1995). Thus, different theoretical approaches have been proposed concerning the types of legitimacy (Meyer \& Rowan, 1977; DiMaggio \& PowelL, 1983; Aldrich \& Fiol, 1994; Scott, 1995; Suchman, 1995). The effects of each type of legitimacy on diverse performance metrics has been measured through multiple indicators: IPO share values, stock prices (Zuckerman, 2000; Pollack, Rutherford, \& Nagy, 2012), stock market risk (Bansal \& Clelland, 2004), and interest group support (Choi \& Shepherd, 2005).

This lack of standardization in legitimacy types has made each author adapt their theoretical constructs to different circumstances. In this respect, Litchfield (1956) and Thompson (1956) state that every organizational theory should be constituted by generic concepts that can be adapted to different contexts or organizations in defining empirically testable relationships.

In the attempts to give greater precision to the legitimacy typology Aldrich and Fiol (1994) distinguish between cognitive and sociopolitical legitimacy. For these authors, cognitive legitimation refers to the knowledge we have about a company, while sociopolitical legitimation refers to the appropriateness and right of a company's actions in a given social system of norms and rules. Scott (1995) further divides the sociopolitical dimension into three sub-dimensions: regulatory, cognitive and normative. Regulatory legitimacy would be related to conformity with rules, laws and sanctions; normative legitimacy would be related to the appropriateness of the entity's actions to society's informal norms and values; and cognitive legitimacy would be related to practices that are taken for granted. Suchman (1995) posit a framework based on three types of legitimacy: pragmatic, moral and cognitive. Pragmatic legitimacy emerges from the interests of the organization's stakeholders (i.e. when the activities undertaken by an organization are aligned with their stakeholders' interests). Moral legitimacy emerges from society's values. It refers to whether the way to get results is what should be, according to the given social system; and cognitive legitimacy concerns whether the shape of the organization for achieving its outputs is the best technically, the most efficient and effective. Later on, Archibald (2004) unifies sociopolitical and regulative legitimacy, and combines normative and cognitive legitimacy types creating a new category, which he calls cultural legitimacy. Bansal and Clelland (2004) analyze a new dimension: environmental legitimacy. However, most empirical studies used Scott's or Schuman's typologies (e.g. Zimmerman \& Zeitz, 2002; Lamberti \& Lettieri, 2011; Pollack, Rutherford, \& Nagy, 2012; Riquel \& Vargas, 2013; Díez-Martín, Prado-Román, \& Blanco-González, 2013b). The main divergence between them could be found around regulatory and pragmatic legitimacy. The first based on rules and the second in the interests of the evaluators. Moral and normative legitimacy are treated in a similar way by both authors. Meanwhile, both legitimacy typologies agree on the cognitive dimension and its meaning.

Scholars have noted the need for more studies on the different types of legitimacy in order to improve measurability (Zucker, 1989; Deephouse \& Suchman, 2008; Díez-Martín, Blanco-González, \& Prado-Román, 2010). Another area that needs more work is the analysis of interactions between different types of legitimacy. A clear view of these relationships would allow decision-makers to channel their choices and resources towards the most productive activities. In this sense, Suchman (1995) suggests that moral legitimacy is more difficult to obtain 
than pragmatic legitimacy; he also suggests that cognitive legitimacy is more difficult to attain than moral legitimacy; although the former has a longer-lasting effect than the latter. According to this author, the cognitive dimension of legitimacy is the most powerful as well as the most difficult to obtain and manipulate.

Cognitive legitimacy concerns itself with actions that simplify or help understand decision-making and therefore contribute to solve problems. Cognitive legitimacy derives from internalizing a belief system designed by professionals and scientists where knowledge is specified and codified. Later, this system can be taken for granted as a framework for daily routine and more specialized activities (Scott, 1994). An organization exhibits desirability and acceptance by developing methods, concepts, and ideas that are commonly accepted and considered useful and desirable by professionals and experts in its surrounding environment (Scott, 1995; Zimmerman \& Zeitz, 2002). An organization is considered to display cognitive legitimacy when it is considered that it carries out its activities in the best possible way. This type of legitimacy is knowledge-based rather than interest or judgment-based (Aldrich \& Fiol, 1994). Aldrich and Fiol (1994, p. 648) state that "the highest form of cognitive legitimation is achieved when a new product, process, or service is taken for granted". In contrast to moral or pragmatic legitimacy, it is not so important that the organization's goals or activities are desirable. Rather, it is a matter of whether the technique(s) used to achieve those goals is considered adequate.

Despite this, cognitive legitimacy remains one of the least studied from an empirical point of view. Most of them have been carried out in the entrepreneurship field. For example, Deeds, Mang, and Frandsen (2004) demonstrated the positive role of cognitive legitimacy in attracting resources for new technology ventures. Similarly, Pollack, Rutherford, and Nagy (2012) results suggest that cognitive legitimacy was positively related to amount of funding received by entrepreneurs.in entrepreneurship contexts. Furthermore, Choi and Shepherd (2005) research established that stakeholder support is more likely for those organizations that are cognitively legitimate.

Within this framework, the authors ask: do organizations with greater cognitive legitimacy show greater resources? In addition, do organizations with greater cognitive legitimacy show greater organizational results?

\section{METHODOLOGY}

In a similar manner to Lamberti and Lettieri (2011), who analyze legitimacy strategies in converging industries, our study adopts an explanation-building approach. This methodology has been successfully applied to the study of organizational legitimacy (i.e., Bianchi \& Ostale, 2006; Ahlstrom, Bruton, \& Yeh, 2008; Huarng \& Hui-Kuan, 2011).

\section{Sample}

This study was performed at six Spanish public universities in Madrid's Autonomous Community: 1. Universidad de Alcalá (UAH), 2. Universidad Autónoma de Madrid (UAM), 3. Universidad Carlos III (UC3), 4. Universidad Complutense (UCM), 5. Universidad Politécnica de Madrid (UPM) and 6. Universidad Rey Juan Carlos (URJC). This was because of the regional relevance these organizations have achieved as well as easy access to secondary information on them. This sector is highly institutionalized because of strong government regulation and high entrance barriers. From an organizational standpoint, these universities are already institutionalized, each University has been in existence for more than 15 years, and has surpassed the legitimacy threshold (Zimmerman \& Zeitz, 2002). It is thus a matter of measuring their degree of legitimacy. Choosing these six was justified based on the following criteria: a) there is homogenous information for measuring resources and results among Madrid's Autonomous Community universities, b) there is a similar competitive environment, at least concerning regional government regulations unto which they are subject, and c) the six universities offer a cross-sample of business models and strategies in higher education.

\section{Data collection and variable measurement}

In order to examine the legitimacy effect on organizational resources and results, eight variables were analyzed.

\section{Cognitive legitimacy}

According to Ruef and Scott (1998:880), "whether an organization is legitimate, or more or less so, is determined by those observers of the organization who assess its conformity to a specific standard or model." Within this framework cognitive legitimacy $(\mathrm{CL})$ in the six universities was measured through individual surveys completed by students, during the fourth quarter of 2011, using a random sampling procedure. Singh, Tucker, and House (1986) measure legitimacy using external sources. Table 1 shows the number of student participants in the survey by university (sample error $=3,46$ ).

There were 10 variables in the survey, which participants were asked to rate on a 5-point Likert scale (Cronbach Alpha: .94). In a similar vein, Human and Provan (2000), Rutherford 
and Buller (2007), and Low and Johnston (2008) use semi-structured interview formats to measure legitimacy. The survey questions asked whether each university could achieve, in the best possible manner, each of the goals suggested by the European Higher Education Area (EHEA). In the next stage, the variables were grouped using factor analysis. In this scale, the results showed only one factor with an eigenvalue greater than one and a cumulative percentage of variance of 68.9\% (KMO: .958). Cognitive legitimacy values for each university were obtained by averaging the variables.

\section{Organizational results and resources}

To measure each university's resources and results we followed criteria given by the Organization for Economic Co-operation and Development (OECD). This organization has established leading indicators for Higher Education.

Universities resources were measured by: a) the number of university professors per student $(\mathrm{Pf} / \mathrm{S}), \mathrm{b})$ the number of staff per student (St/S) and c) total number of employees divided by budget allocated to personnel (E/Bdgt).

Data on number of professors, staff, and students was obtained from the Instituto Nacional de Estadística (INE, 2011). Budgetary information was obtained from the Boletín Oficial de la Comunidad de Madrid (2011).

The following indicators were used for measuring results: a) the number of graduates divided by the total amount of stu- dents (Sf/S), b) the number of students that have obtained work during the last three years, divided by the number of graduates (Sw/Sf), c) each university's research productivity (RP) and d) social interest awakened by each university (SI).

The number of students completing their studies was obtained from INE (2011). To calculate Sw/Sf we used a dataset from Gracia (2012). Research productivity came from Buela-Casal, Bermúdez, Sierra, Quevedo-Blasco, Castro and GuillénRiquelme. (2011). Finally, social interest was derived from the results facilitated by the application of Google search statistics, also known as Google Insights or Trends. A search was performed for the names and acronyms of each university during 2011. The results provided are normalized on a 0-100 scale and provide the number of times a term has been searched in relation to the total number of Google searches over that time period. Other authors have used this indicator to measure social interest (Vosen \& Schmidt, 2011; Hand \& Judge, 2012).

\section{RESULTS}

Table 1 shows the results obtained on all indicators in Madrid's public universities. Universities are ranked according to the degree of cognitive legitimacy provided by student evaluations. Therefore, UAM has the greatest legitimacy while UAH has the least. Data statistical significance were assessed using the t-test. This test confirms a significant difference between the results $(<0,05)$, which allows a comparison between universities.

\section{TABLE 1. Cognitive legitimacy, resources and results in Madrid's public universities}

\begin{tabular}{|c|c|c|c|c|c|c|c|c|c|}
\hline & & & \multicolumn{2}{|c|}{ Resources } & & \multirow{2}{*}{$\frac{\text { Results }}{\text { Sf/S }}$} & \multirow[b]{2}{*}{$\mathrm{Sw} / \mathrm{Sf}$} & \multirow[b]{2}{*}{ RP } & \multirow[b]{2}{*}{ SI } \\
\hline Univ & $\mathrm{N}^{*}$ & $C L$ & $\mathrm{Pf} / \mathrm{S}$ & $\mathrm{St} / \mathrm{S}$ & $\mathrm{E} / \mathrm{Bdgt}$ & & & & \\
\hline UAM & 105 & 2.284 & 0.113 & 0.038 & 0.028 & 0.181 & $75 \cdot 5$ & 67.5 & 69.0 \\
\hline UPM & 47 & 2.277 & 0.094 & 0.066 & 0.025 & 0.137 & 69.6 & 33.3 & 14.0 \\
\hline UC3 & 165 & 2.156 & 0.111 & 0.038 & 0.029 & 0.159 & 75.8 & 63.7 & 8.0 \\
\hline Median & -- & 2.129 & 0.105 & 0.042 & 0.029 & 0.154 & 73.4 & 51.0 & 28.5 \\
\hline URJC & 167 & 2.102 & 0.056 & 0.019 & 0.030 & 0.149 & 78.3 & 33.6 & 43.0 \\
\hline Average & -- & 2.087 & 0.098 & 0.045 & 0.028 & 0.161 & 73.4 & 50.0 & 33.0 \\
\hline UCM & 228 & 1.904 & 0.099 & 0.066 & 0.027 & 0.134 & 71.3 & 52.1 & 56.0 \\
\hline $\mathrm{UAH}$ & 71 & 1.799 & 0.117 & 0.047 & 0.031 & 0.206 & 69.7 & 49.9 & 8.0 \\
\hline t-student & & 0.000 & 0.000 & 0.002 & 0.000 & 0.000 & 0.000 & 0.000 & 0.029 \\
\hline \multicolumn{2}{|c|}{ *error $=3.46$} & & & & & & & & \\
\hline
\end{tabular}

UAH= Universidad de Alcalá, UAM= Universidad Autónoma de Madrid, UC3= Universidad Carlos III, UCM= Universidad Complutense, UPM= Universidad Politécnica de Madrid and URJC= Universidad Rey Juan Carlos.

$\mathrm{CL}=$ cognitive legitimacy, $\mathrm{Pf} / \mathrm{S}=$ no. of professors per student, $\mathrm{St} / \mathrm{S}=$ no. of staff per student, $\mathrm{E} / \mathrm{Bdgt}=$ no. of employees divided by budget, $\mathrm{Sf} / \mathrm{S}=$ no. of graduates divided by the total amount of students, $\mathrm{Sw} / \mathrm{Sf}=$ no. of students that have obtained work during the last three years, divided by the no. of graduates, $\mathrm{RP}=$ university's research productivity, $\mathrm{SI}=$ social interest 
Analyzing these results, of the three universities with $\mathrm{CL}$ greater than the median, two of them (UAM and UC 3 ) also show $\mathrm{Pf} / \mathrm{S}$ ratios over the median. Inversely, among universities with lower $\mathrm{CL}$, two of them are also under the median in the $\mathrm{Pf} / \mathrm{S}$ ratio (URJC and UCM). The relationship between $C L$ and St/S shows that only one of the universities with above-median legitimacy (UPM) has greater staff resources. Only two universities support this link (UPM and URJC). With respect to CL and E/Bdgt, Table 1 shows that just UC 3 has above-median $C L$ and staff resources and just UCM shows both indicators below the cutting point. Nevertheless, in this case we consider that UAM and URJC are special cases, since they both show an above average $C L$ and $E / B d g t$.

Figure 2 to 4 shows the relationship between cognitive legitimacy and university resources.

Figure 2. Cognitive legitimacy and professors per student

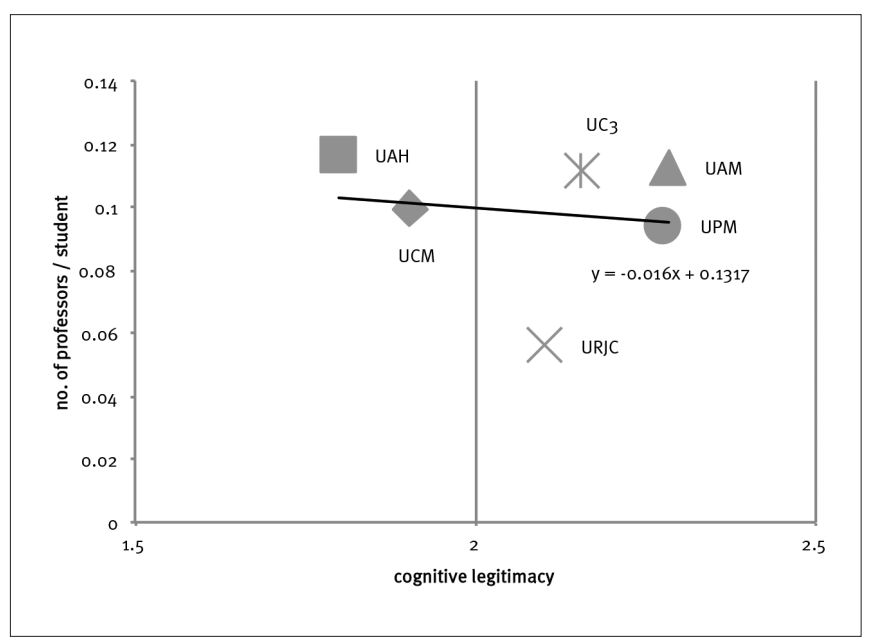

Figure 3. Cognitive legitimacy and number of staff per student

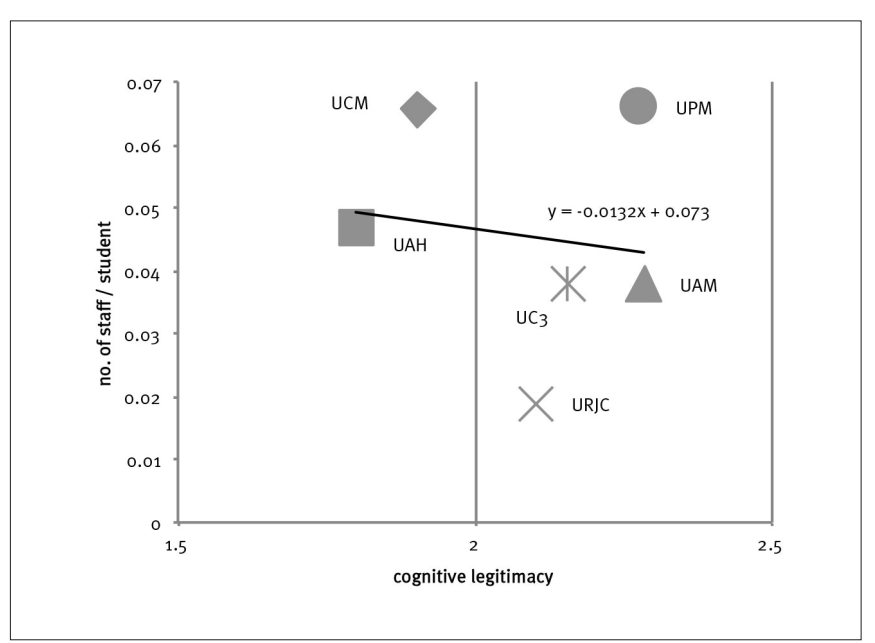

Figure 4. Cognitive legitimacy and employees by budget

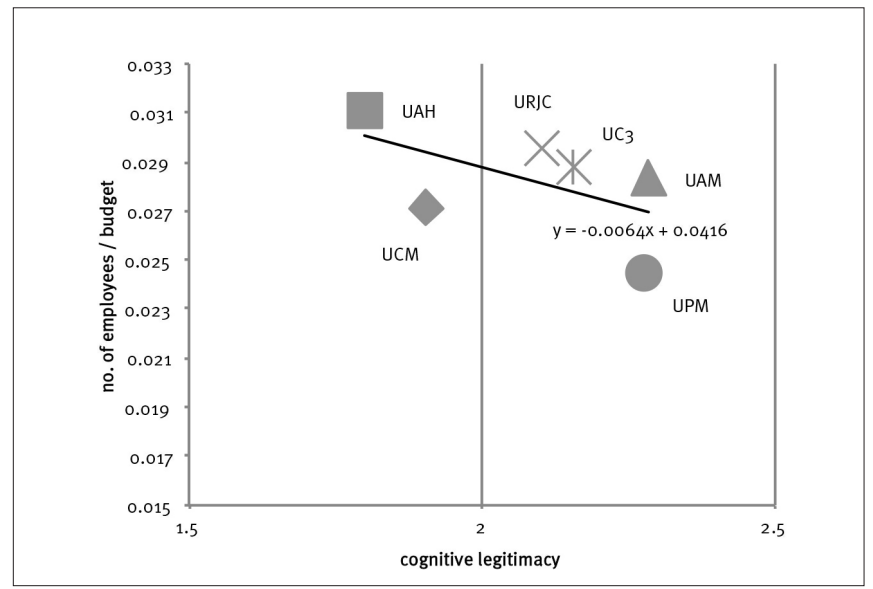

A negative tendency is observed between cognitive legitimacy and university resources. This data is not consistent with literature on the entrepreneurship field. Previous research shows a relationship between cognitive legitimacy and access to resources on new ventures (see Deeds, Mang, \& Frandsen, 2004; or Pollack, Rutherford, and Nagy, 2012). Those analyses focus on non-institutionalized organizations. However, the present research sample is composed by institutionalized organizations with sufficient resources for survival. Meanwhile new ventures need access to resources, in order to survive; institutions are expected to proceed rationally, according to socially established standards. From a cognitive perspective, it means to develop desirable methods and concepts by professionals and experts (Scott, 1995; Zimmerman \& Zeit, 2002), as could be efficiency procedures. These results suggest that among institutionalized organizations, those who are able to manage the fewest resources are perceived by society as those whose activities are carried out in the best manner technically, probably because they are showing efficiency. It seems that for institutionalized organizations, cognitive legitimacy is not related to the amount of resources.

The patterns observed in these cases allow the authors to establish the following:

Proposition 1: institutionalized organizations with greater cognitive legitimacy are not related to greater resources.

In the study of CL and Sf/S, UAM, UPM, UC3 and URJC pass the above-stated criteria. There is no clear support of the assertion that universities with a greater $C L$ also have more students finishing their studies. However, students that obtain work in the three years after finishing their studies are also more numerous in universities with greater $C L$. This is the case 
for UAM, UC 3 , UCM, and UAH. URJC could also be added to this assertion, since its results are above average. Finally, four universities (UAM, UC3, URJC y UAH) show data that supports a link between $\mathrm{CL}$ and RP. With respect to the other results, social interest (SI), only two universities reflect a possible relationship (UAM and UAH), and possibly URJC if we consider average values.

Figure 5 to 8 shows the relationship between cognitive legitimacy and university results.

Figure 5. Cognitive legitimacy and students that have finished their studies

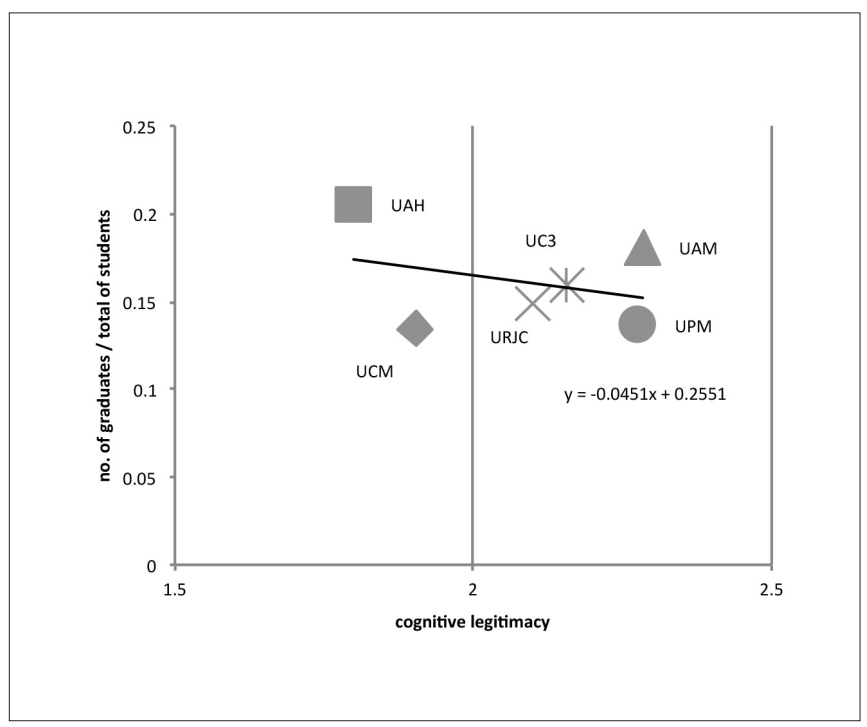

Figure 6. Cognitive legitimacy and students that have obtained work

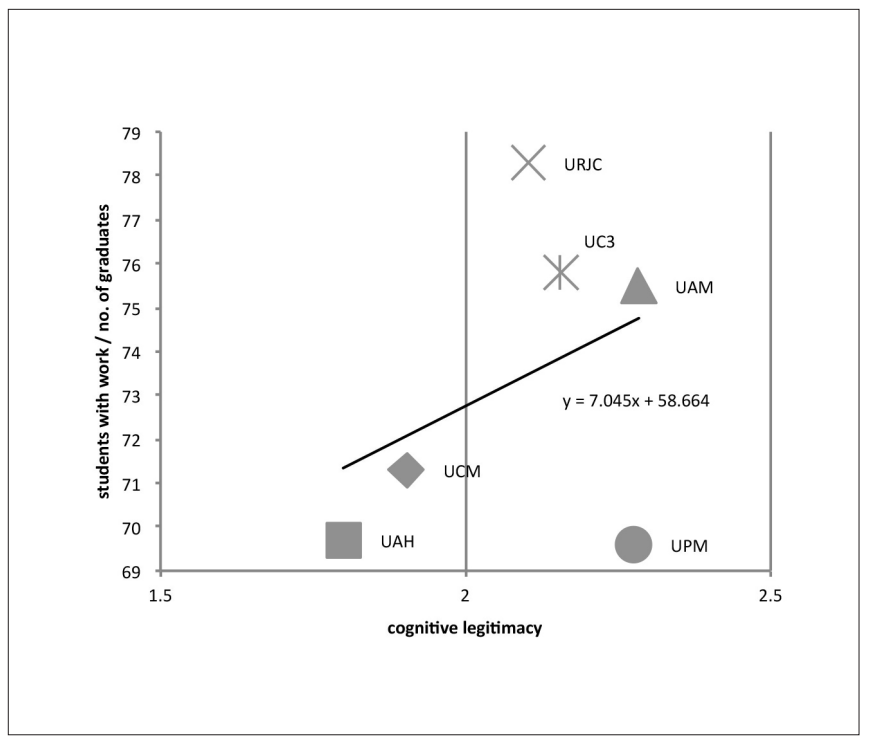

Figure 7. Cognitive legitimacy and university's research productivity

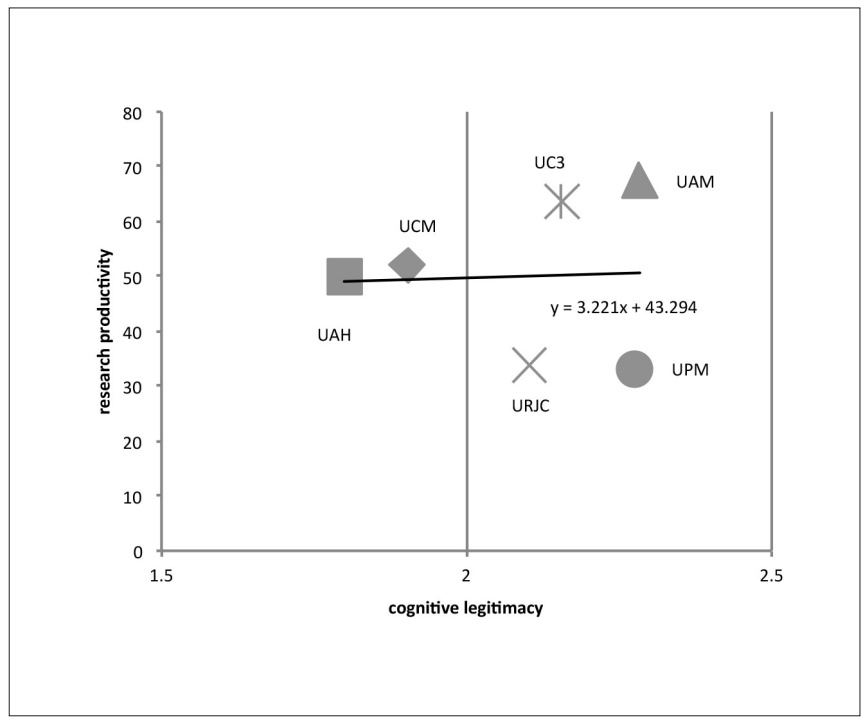

Figure 8. Cognitive legitimacy and social interest

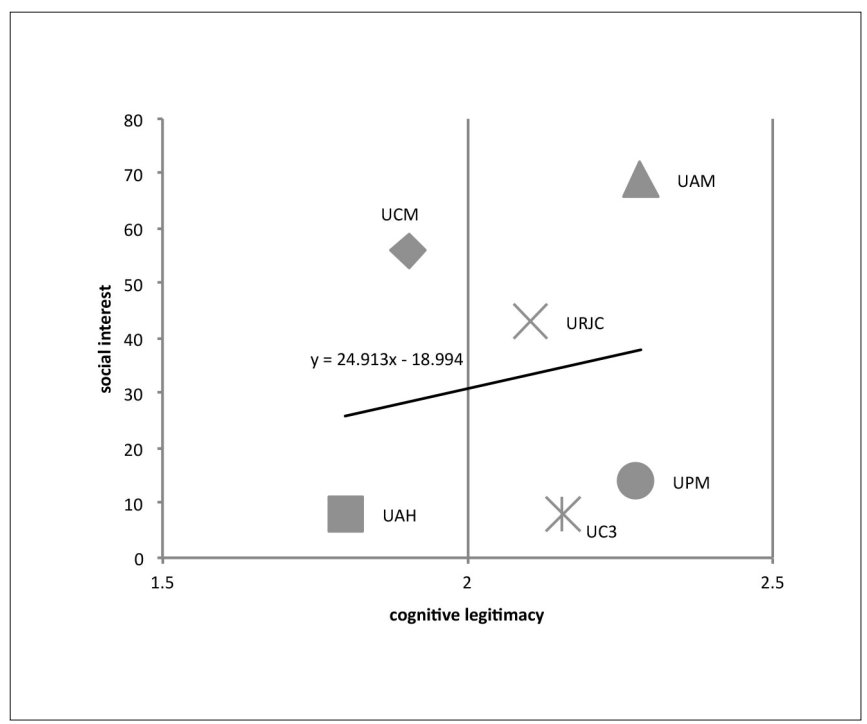

Findings in figure 5 show a negative tendency between cognitive legitimacy and students that have finished their studies. This result could be caused because of the social belief that universities with many graduating students are not adequately demanding to their students, while those in which there are fewer graduates represent most demanding universities which do things technically. However, figure 6 to 8 show what appears to be a positive tendency between cognitive legitimacy and organizational results, both for the number of students that have obtained work during the last three years, research productivity and social interest awakened by each university. These results concord with the theoretic suggestions of Suchman (1995), as well as with Zimmerman and Zeitz's (2002) legitimation process 
and Institutional Theory authors Meyer and Rowan (1977) or Scott (1995). Universities whose methods, concepts, and ideas are most commonly accepted and considered useful will allow their graduates to get a job most easily. Furthermore, those methods will serve to improve their scholar research productivity, and finally, it will also generate more social interest. In light of these facts, we propose the following:

Proposition 2: organizations with greater cognitive legitimacy have better organizational results.

\section{CONCLUSION}

In order to understand the legitimation process further, the authors implemented a case study of six institutions. The focus of this study was the relationship between cognitive legitimacy and organizational success. After evaluating the results, the following propositions were made: a) institutionalized organizations with greater cognitive legitimacy are not related to greater resources; b) organizations with greater cognitive legitimacy have better organizational results. A study of the literature showed a link between overall organizational legitimacy and improved results and/or access to resources (Singh, Tucker, \& House, 1986; Baum \& Oliver, 1991; Hannan \& Carroll, 1992; Pollock \& Rindova, 2003; Rossoni \& Machado-Da-Silva, 2013) but this relationship had not been sufficiently explored concerning cognitive legitimacy. In fact, most studies use other types of legitimacy (see Ruef \& Scott, 1998; Bansal \& Clelland, 2004; Cohen and Dean, 2005; Higgins \& Gulati, 2003, 2006). Therefore, this paper partially fulfills a deficiency in the study of cognitive legitimacy, the most important type from an organizational standpoint (Aldrich \& Fiol, 1994; Suchman, 1995). Future research in this area should start by testing the propositions put forward in this paper. Besides, research along these lines could include a greater number of cases and attempts to test what type of legitimacy is more durable or efficient.

The present study has shown different results regarding the links between cognitive legitimacy and organizational resource (e.g. Deeds, Mang, \& Frandsen, 2004; Choi \& Shepherd, 2005; or Pollack, Rutherford, and Nagy, 2012). Previous research on cognitive legitimacy advocates a positive relationship between both variables. However, our research does not confirm it. We believe that this happened because of the different samples analyzed. Most samples in previous studies on cognitive legitimacy were new ventures, while the sample of this research was institutionalized organizations. This research suggests that in order to analyze relations between cognitive legitimacy and organizational resources, scholars must clearly distinguish results from both new ventures and institutions. Therefore, this should also be applied to the strategic management of cognitive legitimacy. Nevertheless, future studies could analyze this relationship in more depth, differentiating between types of organizations. Suchman (1995) proposed to analyze it between industries. Future research could also study the relationship between cognitive legitimacy and resource management, as efficiency techniques.

Another implication of this study is that not managing cognitive legitimacy is putting oneself at risk of not getting better results. As previous research, this study confirms that organizations with greater cognitive legitimacy have better organizational results. Our study suggests that universities with greater cognitive legitimacy are related to greater graduate employability, research productivity and social interest. These findings are consistent with previous research (Deephouse, 1996; Deephouse and Carter, 2005; Rossoni \& Machado-Da-Silva, 2013). It would thus be recommendable to set cognitive legitimacy as a strategic goal. Theory has long supported this view by considering legitimacy a critical factor for organizational success (Meyer \& Rowan, 1977; Zucker, 1987; Suchman, 1995; Brown, 1998; Zimmerman \& Zeitz, 2002). Actual legitimacy management could follow the blueprint set forth by Suchman (1995), with a compendium of strategies, to earn, maintain, and recover lost legitimacy. Success in applying these strategies has been documented in the probiotic market (Lamberti \& Lettieri, 2011) and nascent organizations (Tornikoski \& Newbert, 2007). In this case, not only institutions, but also nascent organization administrators could implement actions towards improving their legitimacy (Tornikoski \& Newbert, 2007; Mitra, 2009), specially their cognitive legitimacy (Shepherd \& Zacharakis, 2003).

Despite the usefulness of the findings, there are certain limitations. By studying public universities in Madrid, the researchers cannot make valid speculations about the relative efficacy of cognitive legitimacy. By limiting the universe to a specific type of organization, the results are most directly applicable to this specific sector. Moreover, a larger sample size would facilitate the use of quantitative analysis techniques such as regression analysis. In addition, data for the analysis of legitimacy in these universities was obtained solely from the responses given by students of the said organizations. In general, future research in this area should advance towards the analysis of organizational legitimacy with both internal and external data sources (Ruef \& Scott, 1998). Different components of legitimacy could also be introduced in the study (Deephouse \& Suchman, 2008) to measure what type of legitimacy has a greater effect on organizational results. 


\section{REFERENCES}

Ahlstrom, D., Bruton, G. D., \& Yeh, K. S. (2008). Private firms in China: building legitimacy in an emerging economy. Journal of World Business, 43(4), 385-399.

Alcantara, L., Mitsuhashi, H., \& Hoshino, Y. (2006). Legitimacy in international joint ventures: It is still needed. Journal of International Management, 12(4), 389-407.

Aldrich, H. E. \& Fiol, C. M. (1994). Fools rush in? The institutional context of industry creation. Academy of Management Review, 19(4), 645-670.

Archibald, M. E. (2004). Between isomorphism and market partitioning: How organizational competencies and resources foster cultural and sociopolitical legitimacy, and promote organizational survival. In JOHNSON, C. Ed, Research in the Sociology of Organizations, Amsterdam: Elsevier JAl. 22, pp. 171-211.

Ashforth, B. E. \& Gibbs, B. W. (1990). The double-edge of organizational legitimation. Organization Science, 1(2), 177-194.

Bansal, P. \& Clelland, I. (2004). Talking trash: legitimacy, impression management, and unsystematic risk in the context of the natural environment. Academy of Management Journal, 47(1), 93-103.

Barreto, I. \& Baden-Fuller, C. (2006). To conform or to perform? Mimetic behaviour, legitimacy-based groups and performance consequences. Journal of Management Studies, 43(7), 1559-1581.

Baum, J. A. C. \& Oliver, C. (1991). Institutional linkages and organizational mortality. Administrative Science Quarterly, 36(2), 187-218.

Beelitz, A. \& Merkl-Davies, D. (2012). Using discourse to restore organisational legitimacy: 'CEO-speak' after an incident in a German nuclear power plant. Journal of Business Ethics, 108(1), 101-120.

Bianchi, C. C. \& Ostale, E. (2006). Lessons learned from unsuccessful internationalization attempts: examples of multinational retailers in Chile. Journal of Business Research, 59(1), 140-147.

Bronn, P. S. \& Vidaver-Cohen, D. (2009). Corporate motives for social initiative: legitimacy, sustainability, or the bottom line? Journal of Business Ethics, 87(1), 91-109.

Brown, A. D. (1998). Narrative, politics and legitimacy in an IT implementation. Journal of Management Studies, 35(1), 35-58.

Buela-Casal, G., Bermúdez, M. P., Sierra, J. C., Quevedo-Blasco, R., Castro, A., \& Guillén-Riquelme, A. (2011). Ranking de 2010 en producción y productividad en investigación de las universidades públicas españolas. Psicothema, 23(4), 527-536.

Choi, Y. R. \& Shepherd, D. A. (2005). Stakeholder perceptions of age and other dimensions of newness. Journal of Management, 31(4), 573-596.

Cohen, B. D. \& Dean, T. J. (2005). Information asymmetry and investor valuation of IPOs: top management team legitimacy as a capital market signal. Strategic Management Journal, 26(7), 683-690.

Deeds, D. L., Mang, P. Y., \& Frandsen, M. L. (2004). The influence of firms' and industries' legitimacy on the flow of capital into high-technology ventures. Strategic Organization, 2(1), 9-34.

Deephouse, D. L. (1996). Does isomorphism legitimate? Academy of Management Journal, 39(4), 1024-1039.

Deephouse D. L. \& Carter S. (2005). An examination of differences between organizational legitimacy and organizational reputation. Journal of Management Studies, 42(2), 329-360.
Deephouse D. L. \& Suchman M. C. (2008). Legitimacy in Organizational Institutionalism. In Greenwood, R., Oliver, C., Suddaby, R., \& Sahlin-Andersson, K. eds., The Sage Handbook of Organizational Institutionalism. Sage: London, pp. 49-77.

Diez-Martin, F., Blanco-González, A., \& Prado-Román, C. (2010). Legitimidad como factor clave del éxito organizativo. Investigaciones Europeas de Dirección y Economía de la Empresa, 16(3), 127-143.

Díez-Martín, F., Prado-Román, C., \& Blanco-González, A. (2013a). Efecto del plazo de ejecución estratégica sobre la obtención de legitimidad organizativa. Investigaciones Europeas de Dirección y Economía de la Empresa, 19(2), 120-125.

Díez-Martín, F., Prado-Román, C., \& Blanco-González, A. (2013b). Beyond legitimacy: legitimacy types and organizational success. Management Decision, 51(10), 1954-1969.

DiMaggio, P. J. \& Powell, W. W. (1983). The iron cage revisited - institutional isomorphism and collective rationality in organizational fields. American Sociological Review, 48(2), 147-160.

Gracia, A. 2012. La Rey Juan Carlos es la más rápida en colocar a sus licenciados; la Complutense, la que menos. El Confidencial. Access on 11/09/2012 in http://www.elconfidencial.com/espana/2012/06/25/ la-rey-juan-carlos-es-la-mas-rapida-en-colocar-a-sus-licenciados-lacomplutense-la-que-menos-100678.

Greenwood, R., Suddaby, R., \& Hinings, C. R. (2002). Theorizing change: the role of professional associations in the transformation of institutionalized fields. Academy of Management Journal, 45(1), 58-80.

Hand, C. \& Judge, G. (2012). Searching for the picture: forecasting UK cinema admissions using Google Trends data. Applied Economics Letters, 19(11), 1051-1055.

Hannan, M. T. \& Carroll, G. R. (1992). Dynamics of organizational populations: density, legitimation, and competition. Oxford University Press: New York.

Haveman, H. A. \& David, R. J. (2008). Ecologists and institutionalists: friends or foes? In Greenwood, R., Oliver, C., Suddaby, R. \& Sahlin-Andersson, K. eds. The Sage Handbook of Organizational Institutionalism, Sage: London, pp. 573-598.

Higgins, M. C. \& Gulati, R. (2003). Getting off to a good start: the effects of upper echelon affiliations on underwriter prestige. Organization Science, $14(3), 244-263$.

Higgins, M. C. \& Gulati, R. (2006). Stacking the deck: the effects of top management backgrounds on investor decisions. Strategic Management Journal, 27(1), 1-25.

Huarng, K-H. \& Hui-Kuan, T. (2011). Entrepreneurship, process innovation and value creation by a non-profit SME. Management Decision, 49(2), 284-296.

Human, S. E. \& Provan, K. G. (2000). Legitimacy building in the evolution of small-firm multilateral networks: a comparative study of success and demise. Administrative Science Quarterly, 45(2), 327-365.

Kostova, T. \& Zaheer, S. (1999). Organizational legitimacy under conditions of complexity: The case of the multinational enterprise. Academy of Management Review, 24(1), 64-81.

Lamberti, L. \& Lettieri, E. (2011). Gaining legitimacy in converging industries: evidence from the emerging market of functional food. European Management Journal, 29(6), 462-475.

Lawrence, T. B., Winn, M. I., \& Jennings, P. D. (2001). The temporal dynamics of institutionalization. Academy of Management Review, 26(4), 624-644. 
Li, J. T., Yang, J. Y., \& Yue, D. R. (2007). Identity community, and audience: how wholly owned foreign subsidiaries gain legitimacy in China. Academy of Management Journal, 50(1), 175-190.

Litchfield, E. H. (1956). Notes on a general theory of administration. Administrative Science Quarterly, 1(1), 3-29.

Longenecker, C. O., Neubert, M. J., \& Fink, L. S. (2007). Causes and consequences of managerial failure in rapidly changing organizations. Business Horizons, 50(2), 145-155.

Low, B. \& Johnston, W. (2008). Securing and managing an organization's network legitimacy: the case of Motorola China. Industrial Marketing Management, 37(7), 873-879.

Maurer, J. G. (1971). Readings in Organization Theory: Open-System Approaches. Random House: New York.

Meyer, J. W. \& Rowan, B. (1977). Institutionalized organizations: formal structure as myth and ceremony. American Journal of Sociology, 83(2), 340-363.

Mitra, J. (2009). Learning to grow: how new, small, high technology firms acquire cognitive and socio-political legitimacy in their regions. International Journal of Technology Management, 46(3-4), 344-370.

Pollock, T. G. \& Rindova, V. P. (2003). Media legitimation effects in the market for initial public offerings. Academy of Management Journal, 46(5), 631-642.

Pollack, J. M., Rutherford, M. W., \& Nagy, B. G. (2012). Preparedness and cognitive legitimacy as antecedents of new venture funding in televised business pitches. Entrepreneurship Theory and Practice, 36 (5), 915-939.

Rao, R. S., Chandy, R. K., \& Prabhu, J. C. (2008). The fruits of legitimacy: why some new ventures gain more from innovation than others. Journal of Marketing, 72(4), 58-75.

Riquel, F. J. \& Vargas, A. (2013). Las presiones institucionales del entorno medioambiental: aplicación a los campos de golf. Revista Europea de Dirección y Economía de la Empresa, 1(1), 29-38.

Rossoni, L. \& Machado-Da-Silva, C. L. (2013). Legitimidade, governança corporativa e desempenho: Análise das empresas da BM\&F Bovespa. RAE-Revista de Administração de Empresas, 53(3), 272-289.

Ruef, M. \& Scott, W. R. (1998). A multidimensional model of organizational legitimacy: hospital survival in changing institutional environments. Administrative Science Quarterly, 43(4), 877-904.
Rutherford, M. W. \& Buller, P. F. (2007). Searching for the legitimacy threshold. Journal of Management Inquiry, 16(1), 78-92.

Scott, W. R. (1995). Institutions and organizations. Sage, Thousand Oaks: CA.

Scott, W. R. (1994). Institutions and organizations: toward a theoretical synthesis, in Scott, W. R. \& Meyer, J. W, eds., Institutional environments and organizations: Structural complexity and individualism, Sage: Thousand Oaks, CA, pp. 55-80.

Shepherd, D. A. \& Zacharakis, A. (2003). A new venture's cognitive legitimacy: an assessment by customers. Journal of Small Business Management, 41(2), 148-167.

Sheppard, J. P. \& Chowdhury, S. D. (2005). Riding the wrong wave: organizational failure as failed turnaround. Long Range Planning, 38(3), 239-260.

Singh, J. V., Tucker, D. J., \& House, R. J. (1986). Organizational legitimacy and the liability of newness. Administrative Science Quarterly, 31(2), 171-193.

Suchman, M. C. (1995). Managing legitimacy: strategic and institutional approaches. Academy of Management Review, 20(3), 571-610.

Thompson, J. D. (1956). On building an administrative science. Administrative Science Quarterly, 1(1), 102-111.

Tornikoski, E. T. \& Newbert, S. L. (2007). Exploring the determinants of organizational emergence: a legitimacy perspective. Journal of Business Venturing, 22(2), 311-335.

Vosen, S. \& Schmidt, T. (2011). Forecasting private consumption: survey-based indicators vs. Google Trends. Journal of Forecasting, 30(6), 565-578.

Zimmerman, M. A. \& Zeitz, G. J. (2002). Beyond survival: achieving new venture growth by building legitimacy. Academy of Management Review, 27(3), 414-431.

Zucker, L. G. (1987). Institutional theories of organization. Annual Review of Sociology, 13, 443-464.

Zuckerman, E. W. (2000). Focusing the corporate product: securities analysts and de-diversification. Administrative Science Quarterly, 45(3), 591-619. 